\title{
Exploration and Practice of Higher Vocational Education Internationalization
}

\author{
Li Wang ${ }^{1, a}$, Yuewei Ding ${ }^{1, b}$, Yihong Fu ${ }^{1, c}$, Yonghong Lv ${ }^{1, d}$, Hong Chen ${ }^{1, \text { e }}$ \\ ${ }^{1}$ Shanghai Medical Instrumentation College, University of Shanghai for Science and Technology, \\ Shanghai, 200093, China \\ a email: wangl@smic.edu.cn, ${ }^{b}$ dingyw@smic.edu.cn, ${ }^{c}$ fuyh@smic.edu.cn, \\ IIvyh@smic.edu.cn, ${ }^{\mathrm{e}}$ chenh@smic.edu.cn
}

Keywords: Higher Vocational Education; Internationalization; Practice; International Ixchanges and Cooperation

\begin{abstract}
The higher vocational education internationalization is the important means for the vocational colleges to enhance the educational level and personnel training quality .It is also the objective requirements of the higher vocational education. This essay focuses on the common problems in the higher vocational education internationalization(HVEI), analyzes the necessities of higher vocational education internationalization and puts forward the ideas and initiatives to build an effective implementation of higher vocational education internationalization path and management mode. The writer takes the example of Shanghai Medical Instrumentation College (SMIC) to analyze and summarize the higher vocational education international exploration and practice experience.
\end{abstract}

\section{Introduction}

HVEI is to cultivate high-quality technology applied talents with international vision and to raise the overall strength of the higher vocational colleges in China. Either cultivating the international high-quality high-skilled personnel or the construction of a modern vocational education system needs to fully learn from and absorb the useful experience of the developed countries, which further accelerate the process of internationalization of higher vocational education. HVEI is the trend of the development of vocational education when the society and economy develop to a certain extent. At the same time, it is also currently the hot spots of higher vocational education. The ultimate goal of international vocational education is to develop an internationally competitive high-quality high-skilled technology applied talents cultivation system. Therefore, with the consideration of local, regional economic development trends and the situation of the college, we should carry out research on the exploration and practice of HVEI and contribute to the introduction of international standards of vocational education and the establishment of higher vocational education international personnel training HVEI system, operation mechanism and development model to build and improve the international practical training model programs and strategies, and gradually form the HVEI with distinctive features.

\section{The Necessities of Higher Vocational Education Internationalization}

Vocational education is one of the important parts of higher education in China which accounts for half of the size of the education .It bears the important task of training a large number of production skilled personnel. Since 2008, the Ministry of Education launched "national model of higher vocational college construction plan", the higher vocational colleges form the distinct characteristics of school-enterprise cooperation, engineering personnel training mode, faculty with working experiences and certificates, construction of experimental training, social services. They have made considerable progress in the connotation construction. The model colleges give full play to the development, reform, management, demonstration and leading role, which riches the international exchanges and cooperation platform and space, but also bring new opportunities and 
challenges for the internationalization of higher vocational education.

With the deepening of China's accession to the WTO and the reform and opening up policy, the developing trend of economic globalization and technological integration of the world market is increasingly competitive. In the meantime, with the advent of the era of knowledge economy, a personnel training of high-end applications has increasingly become the focus of attention. Increasingly frequent international exchanges; international human resources become the core of demand trends and competition. Vocational education is the important foundation for China's economic and social development, the important pillar of the industrialization and modernization, as well as the important measure and means to enhance China's comprehensive national strength and core competitiveness.

Vocational education has the dual attribute including the higher education and vocational education. The nature of higher education is the profound knowledge creation and heritage. As all known that knowledge is international without borders. Therefore, in the higher education reform and development, we need to continue to expand and strengthen the international academic exchanges and cooperation, and to cultivate international talent. Vocational education is not only to impart knowledge to students, but also to develop students' professional skills, especially in the environment of the globalization of the economy. The reform and development of vocational education need to withstand the challenges of the international standards of the international market as well as vocational and technical qualifications.

Facing the new situation and the new requirements for the technical skills talent on their specifications, knowledge and abilities, it is necessary to build a modern vocational education system to adapt to the needs of economic and social development and industrial upgrading, it is imperative to integrate into the world's vocational education system. In the construction of the modern vocational education system of "Chinese characteristics, world-class", the vocational education bears an inescapable historical responsibility, it will play a catalytic role in the convergence of education of vocational colleges, undergraduate, master. To realize the internationalization of higher vocational education, we should exchange and cooperate with international educational institutions, enterprises, and take full advantage of the international education market.

\section{The Ideas and Initiatives of Higher Vocational Education Internationalization}

At present, there are many problems the internationalization of vocational education: educational philosophy and mode have great lag with the reality, the cooperation style is single, the level of cooperation is low and safeguard is ineffective. Therefore, we must sort out our thinking, correct our understanding and fully understand the importance of HVEI and innovate our work to achieve efficient internationalization of HVE. International exchanges and cooperation is the main means of achieving HVEI, essentially concerned with the Internationalization of education philosophy, school-enterprise cooperation, personnel training objectives, curriculum development, staff training, student internships, academic exchange, professional certification, education resources sharing. In the process of HVEI, we need to run a combination of management mode of the three levels and implement three levels of work, grasp every level and carry out all of the elements with the focus of the "internationalization", as shown in Figure 1.

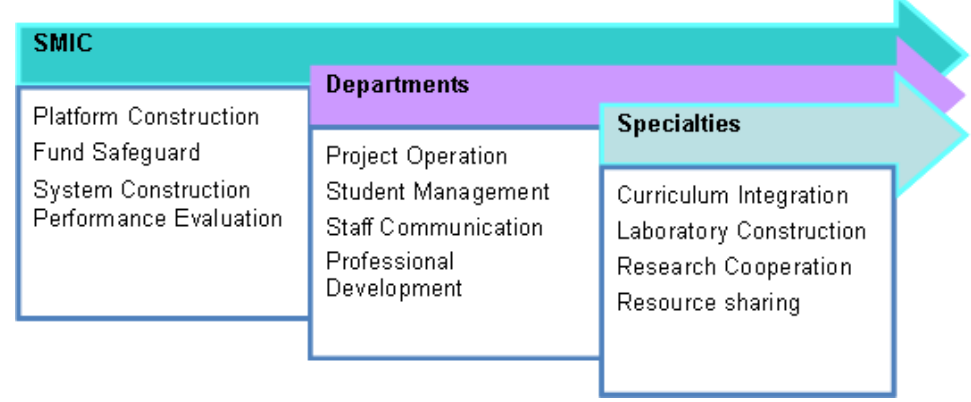

Figure 1. Path and Management Mode Diagram of HVEI 
In the process, it is the important prerequisite to have a clear and accurate international idea for the implementation of the strategy of internationalization of education. Through the International perspective, we could know and understand the nature and effect of higher vocational education. The key of vocational education is school-enterprise cooperation, and internationalization of the school-enterprise cooperation reflects the important direction of HVEI. Vocational colleges are the training bases for applied talents. For the society and business, they demand for high-quality talent with international vision, innovation and practical ability, which became the main objective of cultivating internationalized talent.

\section{Exploration and Practice of Higher Vocational Education Internationalization}

Shanghai Medical Instrumentation College is the only one college, which is set independently specialized in cultivating highly skilled personnel in medical equipment .It has more than half a century of history. Backed by industries and enterprises, it has distinct educational characteristics. The medical instrumentation specialties are relatively complete; it has distinctive features, which is close to the market. Therefore, it is known as the "cradle of medical equipment technicians and engineers".

SMIC has cultivated the talents with combination of medical engineering, work-oriented, compatible management skills, with a global vision of high-tech medical equipment applications talents. In the last three years, SMIC has speeded up the process of internationalization of the college and promote international cooperation and exchanges, expanded the areas of cooperation, enhanced the level of cooperation and exchanges, expanded the international influence of the college ,implemented the International exploration and practice of vocational education, and achieved good results smoothly.

Platforms and the fund are the primary key issues need to be addressed in the process of vocational colleges to promote the internationalization of education. SMIC fully rely on the opportunities of the projects, in accordance with the overall planning of the college. It has performed international exchanges and cooperation platform for each department according to their own characteristics. According to the operational requirements of the departments of carrying out international exchanges and cooperation projects, SMIC has increased the magnitude of "going out" . In addition to enhancing the international ideas of studying overseas through exchanges and research projects, SMIC targeted to encourage teachers to participate in special training at home and abroad. This has increased the basic teaching ability of teachers and enhanced the integration of international elements. More and more students could take part in the overseas internship programs, because SMIC has encouraged and supported students in professional cooperation on the basis of mutual recognition of credits, internships aiming at locate the student's career literacy and professional skills with the international level. SMIC encourages the specialties to carry out the introduction of the course, mutual recognition of credits, bilingual education, international vocational qualification standards and laboratories building.

SMIC pays more attention to the level of international exchanges and cooperation, focuses on the optimization of its own brand characteristics, highlighting its international characteristics. SMIC carried forward the brand effect of the combining medical with Engineering and existing experimental and training bases and carried out different levels of learning and exchange programs for the students, including internships, undergraduate graduation design as well as graduate research. In the process of internationalization of higher vocational education, SMIC has reinforced its own brand characteristics.

\section{Conclusion}

After three years of exploration and practice, SMIC has enhanced the medical equipment HVEI, realized the internationalization of source of students, faculty, personnel training, training bases and has developed completely new situation of vocational education, key performance shown in Table 1. 
Table 1. Main effect of HVEI

\begin{tabular}{|c|c|}
\hline Effects & Results \\
\hline increasing & $\begin{array}{l}\text { Sign cooperation contacts with } 12 \text { overseas } \\
\text { universities or colleges } \\
\text { 155students overseas study } \\
104 \text { teachers overseas training } \\
90 \text { guests abroad visited } \\
\text { Students from } 2 \text { overseas universities studied } \\
\text { 3.91 million yuan has put into the overseas } \\
\text { internship programs }\end{array}$ \\
\hline Quality enhancement & $\begin{array}{l}\text { Cooperation with the institutions of developed } \\
\text { countries to open up new areas of international } \\
\text { cooperation institutions } \\
\text { Cooperation with the excellent universities to } \\
\text { improve the level of international cooperation } \\
\text { institutions } \\
\text { Overseas well-known professors visiting and } \\
\text { teaching to enhance international cooperation and } \\
\text { exchange of teaching and research } \\
\text { Cooperation with the international well-known } \\
\text { enterprises, in-depth understanding of advanced } \\
\text { foreign companies }\end{array}$ \\
\hline
\end{tabular}

Internationalization of vocational education has expanded the vision of the teachers and students and given them the opportunities to further master the advanced education teaching philosophy and understand industry developing trends. SMIC has great progress in specialty construction, discipline cooperation, personnel exchanges and personnel training. It has build up the international brand of vocational education and expanded the international influence of the college and key constructed specialties.

\section{Acknowledgement}

Our further research of inspiration on the HVEI and the extract from HVEI of SMIC are supported by Shanghai Municipal Education Commission in Research projects B12072 in higher education internationalization fields.

\section{References}

[1] Zhang Xueping ,the consideration of Internationalization of vocational education [J]. Industry and technology forum, 2012,Vol11(2):129-130.

[2] Peng Hai-xiong, Wang Xiao-hua. Research on the Problems and Strategies of the Higher Vocational Education Internationalization[J]. Journal of Hebei Energy Institute of Vocation and Technology,2012,Vol3(1):14-16.

[3] Liu wei. On Internationalization of Vocational Colleges[J]. GUANGZH0U VOCAT10NAL EDUCATION F0RUM, 2012,Vol11(4):56-60.

[4] LUO Xiao - ping, BA0 Ying - lei, YU Shu - shu. Research on International Exchanges and Cooperation Strategy in Exemplary Higher Vocational Colleges [J]. JOURNAL OF HUNAN INDUSTRY POLYTECHNIK,2012, Vol12(6):134-140.

[5] Liu Xianliang. Thoughts on the Reform and Development of Higher Vocational College (EB/OL), http://sfb.yrcti.edu.cn/showart.asp, 2007-8-23.

[6] Liu Zhengliang. Consideration on Structural Adaptability and Countermeasures of Internati0nalization of Higher Vocational Education[J]. VOCATIONAL AND TECHNICAL EDUCATION, 2008, Vol29(28):32-35.

[7] Su Zhili. Discussion on the Internationalization of Our Country's Higher Vocational Education[J]. Journal of Tianjin Adult Higher Learning, 2005, Vol7(2):98-99. 